\begin{abstract}
Research Article
(C) 2020 Nopi Tikasari and Dwi Asih Surjandari. This is an open access article licensed under the Creative Commons Attribution-NonCommercial 4.o International License (https://creativecommons.org/licenses/by-nc/4.0/)
\end{abstract}

Received: 7 October 2020 / Revised: 27 October 2020 / Accepted: 9 November 2020/ Published: 21 November 2020

\title{
The Determinant of Market-Based Performance: Evidence from Manufacturing Companies in Indonesia
}

\author{
Nopi Tikasari \\ Student of Master Program in Accounting, Universitas Mercu Buana, \\ Jl. Raya, RT.4/RW.1, Meruya Sel., Kec. Kembangan, Jakarta, \\ Daerah Khusus Ibukota Jakarta 1165o, Indonesia \\ Dwi Asih Surjandari \\ Assistant Professor, Department of Accounting, Universitas Mercu Buana, \\ Jl. Raya, RT.4/RW.1, Meruya Sel., Kec. Kembangan, Jakarta, \\ Daerah Khusus Ibukota Jakarta 1165o, Indonesia \\ Corresponding Author
}

DOI: https://doi.org/10.36941/mjss-2020-0o6o

\section{Abstract}

\begin{abstract}
The research aims to explore the determinant of firm's market-based performance in Indonesia manufacturing companies, listed in Indonesia Stock Exchange between 2014 to 2019. The proxies used in this research are Return on Equity (ROE), Leverage, Earning per Share (EPS), Growth, Liquidity (Liquid) and Non-Debt Tax Shield (NDTS). The sampling method employs purposive sampling while the analysis is performed using E-views version 11. The result indicates that in partial, Leverage is negatively significant affect to Firm Performance while the other measured variables, namely Return on Equity, Leverage, Earning Per Share, Liquidity and Non-Debt Tax Shield, prove to be insignificant affect to firm performance. All variables simultaneously affect strongly on Firm Performance. This research implies that the management of the firm should observe Return on Equity (ROE), Leverage, Earning- per Share (EPS), Growth, Liquidity (Liquid) and Non-Debt Tax Shield (NDTS) closely in developing their strategy for better firm performance.
\end{abstract}

Keywords: firm performance determinant, Manufacturing, Indonesia

\section{Introduction}

High performing firm attracts wide ranges of stakeholders with different interest. Typically, there are two performance dimensions that stakeholders observed, which are financial performance and nonfinancial performance (Santos and Brito, 2012).

Financial performance is measured not only by the growth rate and its profitability, but also by instances such as economic value. On the other hand, non-financial performance is broader with each stakeholder seek for particular company information in accordance to its agenda. In a middling approach, Jensen (2001) reconciled for both social and economic theory to come up with stakeholder satisfaction measurement as a tool for firm's performance measurement.

Following Jensen combined approach, Al-Matari et al (2014) developed measurement of firm's performance on the basis of stakeholder's approach comingling accounting measurement with market-based performance to reflect the interest of stakeholders with its long-term view. 
Previous studies set ranges of variables as the determinant of firm performance, among others are Firm Size (Al Qaisi et al, 2016; Sharif et al, 2015), Age of the Firm (Al Qaisi et al,.2016) Firm's Growth, Fixed Asset, Working Capital, Leverage (Punchir, 2014; Jafari and Al Saman, 2015; Al Azam, 2014; Al Qaisi et al.,2016), Sales Growth divided byAsset Growth (Jayasiri, 2015 ; Al Azam, 2014)), Return on Asset ( Burja, 2011; Al Qaisi et al. ,2016), Return on Equity, Book Value per-share, Price Earnings Ratio, Dividend per share/yield, Earning-Per Share (Al Tamimi et al., 2009; Sharif et al. ,2015). Furthermore, various variables have reached heterogenous conclusion in contributing firm's performance. Al Qaisi et al. (2016) found that ROE does not affect firm performance, while Sharif et al. (2014) found that ROE affected firm performance. Al-Qaisi et al. (2016) also found that leverage affected firm performance, while Punchir (2014) found otherwise. EPS was also drawn to have positive effect (Al Tamimi et al, 2009) as well as negative effect to firm performance (Sharif et al, 2014).

Furthermore, sales growth did not affect firm's performance, while asset growth told otherwise (Jayasiri, 2015). Meanwhile, liquidity negatively affected performance (Calistus et al., 2018, Anastasia et al., 2014, Mohammad et al., 2019) while other researches found that liquidity positively affect firm's performance (Grace, 2015; Kartal, 2016; Al Nimer et al., 2015). Mixed result was also drawn in the study by Saleem et al. (2011).

Among those related variables, Non-Debt Tax Shield has not been explored extensively, with only the work of Sritharan (2015) concluded that there is negative relation between Non-Debt Tax Shield with Firm Performance. Based on the importance of market-based measurement of performance and the variation in result on its effect to performance from previous studies, this research explores the determinant of market-based measurement performance, which represented by Return on Equity (ROE), Leverage, Earning per Share (EPS), Growth, Liquidity (Liquid) and NonDebt Tax Shield (NDTS) of manufacturing companies listed in Indonesia Stock Exchange between 2014 to 2019.

\section{Theoretical Review}

\subsection{The Grand Theory: The Agency, Stakeholder and Pecking Order Theory}

Agency Theory describes agent relation as consequences of the inability of firm's shareholder to directly execute business plan by themselves, appointing third parties known as management (Berk et al., 2011). The main task of management is to increase firm's value, thus, the management must place their best effort to maximize firm's value, hence, shareholder's value (Brigham and Houston, 2014). On the other hand, stakeholder theory acknowledge the presence of a person or group, such as shareholder, employee, customer, local community or even government, that could influence or could be influenced by activities of firm's profit making (Friedman and Miles, 2006). Given its presence, the management of firm are bound by all interest parties interacted with the firm when running the company. Meanwhile the Pecking Order Theory states that there is a hierarchy in financing decision. First, firm will choose internal source and hope it is precepted as a good news by the investor and when external source needed it must add value for the firm in order to be precepted as a good news either by the investor.

\subsection{Literatures supported to Dependent Variable}

Management success in managing a firm could be observed by both financial and non-financial aspect (Hansen and Mowen, 2007; Santos dan Brito, 2012). The specific measurement to firm's performance recorded by Al-Matari et al. (2014) are Accounting Based Measurement (ABM) and Market Based Measurement (MBM). ABM measures performance based on accounting concepts that shows the effective indicator of firm in obtaining profit. It is usually measured by Return on Asset (ROA), Return on Equity (ROE), Return on Sales (ROA) or Return on Investment (ROI) and other profit measurement. Santos dan Brito (2012) argued that these measurements are short term, hence, 
has limited capacity to portray firm's performance. Thus. Selvam (2016) suggested the use of multiple measurement in assessing firm performance. Furthermore, MBM measures firm's performance on the basis of its market value, which involves future aspect that reflected shareholder's expectation of firm future performance as well as considers the other stakeholder's interest. This places market value as an indicator of firm performance usually represented by Tobin's Q formula, Market Value Added (MVA), Market to Book Value (MTBV). Among these variables, Tobin's Q formula has been used the most. (Al Matari et all, 2014).

\subsection{Literatures supports Independent Variables}

Return on Equity (ROE) is a portion of net income for shareholder (Titman, Keown, Martin, 2014), both for common and preferred shareholders. High ROE is often considered as better firm performance. The study by Sharif et all (2015) stated that ROE had significant effect on MBM of performance.

Leverage shows the portion of external funding, calculated as a portion of debt to equity or debt to total asset (Titman, Keown, Martin, 2014). According to pecking order theory, leverage will affect firm performance, either positive or negative. This is in line with works by Al Azam (2014), Wydia et al. (2015), Jafari(2015).

Earnings Per Share (EPS) describes net income obtained for every share. It is calculated as net profit after deducted by the portion for preferent share then divided by the amounts of outstanding shares. In general, high EPS is translated into higher firm's performance. This is supported by works of Tamimi et al. (2009) and Rudi (2018), which concluded that EPS significant affected on MBM firm's performance

Growth shows the trend of change, whether increase or decrease from respective year, which usually measured as sales or asset growth. Sales growth is calculated as:

Growth $_{\text {sales }}($ sales $\mathrm{t}-$ sales $\mathrm{t}-1) /$ sales $\mathrm{t}-1$

while asset growth calculated as follow:

Growth $_{\text {asset }}$ (growth year $\mathrm{t}$ - growth year $\mathrm{t}-1$ )/ growth year $\mathrm{t}-1$.

High growth leads to better firm performance. This relationship is supported by finding of Jayasiri (2015), Jafari (2015) and Al Azam (2014).

Liquidity refers to the ability of firm in meeting its short- term debt (Titman et al, 2014). It is usually calculated as follow:

Current Ratio $=$ Current Asset $/$ Current Liability

Acid Test Ratio = (Current Asset - Inventory $) /$ Current Liability .

The sound practice of Liquidity gives positive signal to shareholders and an indication of good performance. Thus, Liquidity affect Firm Performance

Non- Debt Tax Shield (NDTS) is related with tax facility from government that firm could use (tax shield), such as depreciation expense. In calculating taxable income, depreciation expense treated as interest expense. This means that higher value of depreciation implies higher tax saving and improves cashflow. With higher cash flow, firm has more space to increase its performance. NDTS affects firm performance in general.

\subsection{Conceptual framework and hypotheses}

The relation between variables (ROE, Leverage, EPS, Growth, Liquidity and NDTS) and Firm performance are shown in Figure 1 below: 


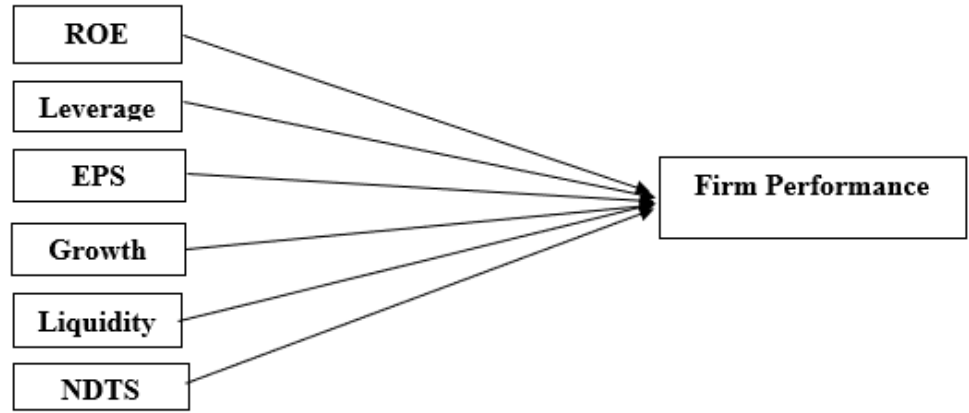

Figure 1. Conceptual Framework

Thus, the hypotheses are constructed as following:

$\mathrm{H}_{1}$ : Return on Equity has positive effect on Firm Performance

$\mathrm{H}_{2}$ : Leverage affects Firm Performance

$\mathrm{H}_{3}$ : Earnings per Share affects Firm Performance

$\mathrm{H}_{4}$ : Growth affects Firm Performance

$\mathrm{H}_{5}$ : Liquidity affects Firm Performance

$\mathrm{H}_{6}$ : Non-Debt Tax Shield affects Firm Performance

\section{Methodology}

\subsection{Research Design and Subject}

This research adopted a confirmatory research, where the hypotheses are tested on their effect to dependent variables: the relationship between ROE, Leverage, EPS, Growth, Liquidity and NDTS to the dependent variable, which is firm performance. The subject of research is manufacturing companies listed in Indonesia Stock Exchange between 2014 to 2019. The sampling used is purposive sampling subject to the availability of data. Data collected through IDX website and Library research.

\subsection{Variable Operationalization}

The variables operated in this research is shown in table 1.

Table 1. Operationalization of research variables

\begin{tabular}{|l|l|c|c|}
\hline Variable & Description & Formula & Scale \\
\hline Firm Performance $(\mathrm{Y})$ & Firm Performance at a certain year & Tobin's Q $=\frac{\text { Share Market Value }}{\text { Total Asset }}$ & Ratio \\
\hline ROE $\left(\mathrm{X}_{1}\right)$ & $\begin{array}{l}\text { Firm's ability in generating profit using } \\
\text { equity owned }\end{array}$ & $\frac{\text { Net Profit }}{\text { Total Equity }}$ & Ratio \\
\hline Leverage (X2) & Debt proportion in Financing to Total Asset & $\frac{\text { Debt Total }}{\text { Asset Total }}$ & Ratio \\
\hline EPS $\left(\mathrm{X}_{3}\right)$ & Profit proportion for each share & $\frac{\text { Net Profit }}{\text { outstanding shares }}$ & Ratio \\
\hline Growth $\left(\mathrm{X}_{4}\right)$ & Company's growth by Asset & $\frac{\text { asset year t-asset yeart }-1}{\text { asset year } t-1}$ & Ratio \\
\hline Liquidity $\left(\mathrm{X}_{5}\right)$ & Firm's ability to fulfill short-term debt & $\frac{\text { Depresiascurrent asset }}{\text { Total Asset }}$ & Rationsen \\
\hline Non-Debt Tax Shield (X6) & Tax benefit because of the law & Ratio \\
\hline
\end{tabular}

Source: 2020 , processed data 


\subsection{Analysis Method}

The research involves panel data, thus regression analysis used which is supported by 11,0 version Eviews through following steps: a) Descriptive Statistic Analysis, b) model estimation, c) model selection, d) classical Assumption Test and e) hypotheses test, comprises : Determination Coefficient Analysis (R2), Statistical F Test, t-Test and multiple linear regression analysis.

\section{Result and Discussion}

\subsection{Descriptive Statistic Analysis}

Table 2. Statistic Descriptive Test result

\begin{tabular}{|c|c|c|c|c|c|c|c|}
\hline & FIRMPER & ROE & LEV & EPS & GROWTH & LIQUID & NDTS \\
\hline Mean & 2.670648 & 0.235982 & 0.376615 & 672.8877 & 0.123058 & 2.794531 & 0.030777 \\
\hline Median & 1.547000 & 0.138563 & 0.336649 & 109.9054 & 0.090054 & 2.396868 & 0.028470 \\
\hline Maximum & 22.55900 & $2.2445^{85}$ & 0.837462 & 8101.439 & 1.050409 & 8.088936 & 0.066251 \\
\hline Minimum & 0.096000 & -0.160562 & 0.119486 & -304.6613 & -0.286635 & 0.605632 & 0.008569 \\
\hline Std. Dev. & 4.038994 & 0.388049 & 0.188983 & 1389.250 & 0.198208 & 1.536530 & 0.014504 \\
\hline Skewness & 3.301590 & 3.535460 & 0.844028 & 3.150835 & 2.256448 & 0.777157 & 0.633854 \\
\hline Kurtosis & 13.72800 & 15.55859 & 2.823432 & 13.54972 & 10.25382 & 3.222380 & 2.543078 \\
\hline Jarque-Bera & 714.1139 & 934.7228 & 12.96319 & $679 \cdot 5340$ & 328.4287 & 11.09406 & 8.171374 \\
\hline Probability & 0.000000 & 0.000000 & 0.001531 & 0.000000 & 0.000000 & 0.003899 & 0.016812 \\
\hline Sum & 288.4300 & 25.48603 & 40.67445 & 72671.88 & 13.29025 & 301.8093 & 3.323877 \\
\hline Sum Sq. Dev. & $1745 \cdot 541$ & 16.11228 & 3.821476 & $2.07 \mathrm{E}+08$ & 4.203655 & 252.6189 & 0.022509 \\
\hline Observations & 108 & 108 & 108 & 108 & 108 & 108 & 108 \\
\hline
\end{tabular}

Source: 11,o version, E-views Output

Firm Performance has minimum of o,0960oo own by INAI in 2015 and maximum of 22,55900 on behalf of UNVR in 2017, with the mean of 2,670648 and standard deviation of 4,038994. The mean of Firm Performance $>1$, which means that market overvalued manufacturing companies in between 2014 and 2019. This can be interpreted as unmeasured/unrecorded assets within reflected market value.

The minimum value of Return on Equity (ROE) is - 0,160562 possessed by LMSH in 2011 and maximum value of 2,244585 own by MERCK in 2018. The mean value of 0,235982 and deviation standard of standard deviation of 0,388049 . The mean of ROE more than $20 \%$, indicated the high return of equity on manufacturing companies between 2014 and 2019 in IDX.

Leverage has minimum value of 0,119486 entitled to EKAD in 2019 and maximum of 0,837462 associated with INAI in 2014. The mean shot at of 0,376615 while the standard deviation rests at 0,188983 . The mean value below 50\% indicated that Indonesia manufacturing companies practiced a sound financing on their capital structure between 2014 and 2019.

Minimum value of EPS is -304.6613 attached to AMFG in 2019 and maximum of 8101.439 that belong to MERCK in 2014. The mean value is at 672.8877 while the standard deviation is at 1389.250 .

Growth has minimum value of -0,286635, owned by MERCK in 2019 and maximum of 1,050409 possessed by ROTI in 2018. The mean value identified at 0,123058 while the standard deviation stayed at 0,198208 . The growth of Indonesian manufacturing companies during 2014 to 2019 quite small.

The Minimum of Liquidity is at 0,605632 belong to UNVR in 2016 and maximum is at 8,0833936 recorded by $\mathrm{LMSH}$ in 2015 . The mean value is at 2,794531 while standard deviation rested at 1,536530. The Indonesian manufacturing companies practiced sound Liquidity for more than 2, indicated a strong liquidity.

Non debt tax shield has minimum value of 0,008569 belong to KAEF in 2019 and maximum value of 0,056251 set by ARNA in 2017. The mean value is at 0,030777 while the standard deviation is at o,014504. Depreciation expense the Indonesian manufacturing companies set around 3\% proportion from total asset, quite small. 


\subsection{Panel Data Regression Model Estimation.}

The result of regression model run using E-Views are presented in table 3, 4, and 5 for Common Effect, Fixed Effect, and Random Effect model respectively.

Table. 3. Common Effect Model

Dependent Variable: FIRMPER

Method: Panel Least Squares

Date: 09/06/20 Time: 11:53

Sample: 20142019

Periods included: 6

Cross-sections included: 18

Total panel (balanced) observations: 108

\begin{tabular}{lllll} 
Variable & Coefficient & Std. Error & t-Statistic & Prob. \\
\hline C & 1.180478 & 2.106542 & 0.560387 & 0.5765 \\
ROE & 7.434896 & 0.884858 & 8.402360 & 0.0000 \\
LEV & 0.296266 & 2.645331 & 0.111996 & 0.9110 \\
EPS & -0.000317 & 0.000221 & -1.433198 & 0.1549 \\
GROWTH & -4.717642 & 1.545784 & -3.051942 & 0.0029 \\
LIQUID & -0.114273 & 0.318526 & -0.358756 & 0.7205 \\
NDTS & 23.96401 & 21.17371 & 1.131781 & 0.2604 \\
\hline Root MSE & 2.892663 & R-squared & 0.482287 \\
Mean dependent var & 2.670648 & Adjusted R-squared & 0.451531 \\
S.D. dependent var & 4.038994 & S.E. of regression & 2.991225 \\
Akaike info criterion & 5.091862 & Sum squared resid & 903.6901 \\
Schwarz criterion & 5.265704 & Log likelihood & -267.9605 \\
Hannan-Quinn criter. & 5.162348 & F-statistic & 15.68144 \\
Durbin-Watson stat & 1.110397 & Prob(F-statistic) & 0.000000 \\
\hline
\end{tabular}

Source: 11,0 version E-views Output

Table 4. Fixed Effect Model

Dependent Variable: FIRMPER

Method: Panel Least Squares

Date: 09/06/20 Time: 11:56

Sample: 20142019

Periods included: 6

Cross-sections included: 18

Total panel (balanced) observations: 108

\begin{tabular}{lllll}
\hline Variable & Coefficient & Std. Error & t-Statistic & Prob. \\
\hline C & 3.135548 & 1.101558 & 2.846467 & 0.0056 \\
ROE & -0.620453 & 0.452912 & -1.369919 & 0.1744 \\
LEV & -0.669489 & 1.539013 & -0.435012 & 0.6647 \\
EPS & $-7.87 \mathrm{E}-05$ & 0.000124 & -0.635778 & 0.5266 \\
GROWTH & 0.270485 & 0.685573 & 0.394539 & 0.6942 \\
LIQUID & 0.037544 & 0.142939 & 0.262656 & 0.7935 \\
NDTS & -4.926538 & 23.61279 & -0.208639 & 0.8352 \\
\hline \multicolumn{5}{c}{} \\
\hline Cross-section fixed (dummy variables) & Effects Specification & \\
\hline Root MSE & 0.886732 & R-squared & 0.951350 \\
Mean dependent var & 2.670648 & Adjusted R-squared & 0.938030 \\
S.D. dependent var & 4.038994 & S.E. of regression & 1.005460 \\
Akaike info criterion & 3.041897 & Sum squared resid & 84.91978 \\
Schwarz criterion & 3.637927 & Log likelihood & -140.2625 \\
Hannan-Quinn criter. & 3.283566 & F-statistic & 71.41892 \\
Durbin-Watson stat & 2.104966 & Prob(F-statistic) & 0.000000 \\
\hline
\end{tabular}

Source: 11,0 version E-views Output 
Table 5. Random Effect Model

Dependent Variable: FIRMPER

Method: Panel EGLS (Cross-section random effects)

Date: 09/o6/20 Time: 11:58

Sample: 20142019

Periods included: 6

Cross-sections included: 18

Total panel (balanced) observations: 108

Swamy and Arora estimator of component variances

\begin{tabular}{|c|c|c|c|c|}
\hline Variable & Coefficient & Std. Error & t-Statistic & Prob. \\
\hline $\bar{C}$ & 2.534560 & 1.055859 & 2.400473 & 0.0182 \\
\hline ROE & 0.646303 & 0.431034 & 1.499426 & 0.1369 \\
\hline LEV & 0.424215 & 1.376836 & 0.308109 & 0.7586 \\
\hline EPS & $-7.51 \mathrm{E}-05$ & 0.000115 & -0.650404 & 0.5169 \\
\hline GROWTH & -0.578079 & 0.638824 & -0.904911 & 0.3677 \\
\hline LIQUID & -0.014732 & 0.138212 & -0.106586 & 0.9153 \\
\hline \multirow[t]{3}{*}{ NDTS } & -0.434085 & 17.34505 & -0.025026 & 0.9801 \\
\hline & \multicolumn{4}{|c|}{ Effects Specification } \\
\hline & & & S.D. & Rho \\
\hline Cross-section random & & & 1.423357 & 0.6671 \\
\hline \multirow[t]{2}{*}{ Idiosyncratic random } & & & 1.005460 & 0.3329 \\
\hline & \multicolumn{4}{|c|}{ Weighted Statistics } \\
\hline Root MSE & 1.403953 & \multicolumn{2}{|c|}{ R-squared } & 0.016973 \\
\hline Mean dependent var & 0.740022 & \multicolumn{2}{|c|}{ Adjusted R-squared } & -0.041424 \\
\hline S.D. dependent var & 1.422623 & \multicolumn{2}{|c|}{ S.E. of regression } & 1.451789 \\
\hline Sum squared resid & 212.8769 & \multicolumn{2}{|c|}{ F-statistic } & 0.290651 \\
\hline \multirow[t]{2}{*}{ Durbin-Watson stat } & 0.922736 & \multicolumn{2}{|c|}{ Prob(F-statistic) } & 0.940156 \\
\hline & \multicolumn{4}{|c|}{ Unweighted Statistics } \\
\hline$\overline{\text { R-squared }}$ & 0.088299 & Mean de & nt var & 2.670648 \\
\hline Sum squared resid & 1591.412 & Durbin- & n stat & 0.123431 \\
\hline
\end{tabular}

Source: 11,o version E-views Output

\subsection{Selection of Panel Data Regression Model}

\subsubsection{Chow Test (Fixed Effect Test)}

Chow Test selects model by comparing common and fixed effect model for testing the hypotheses as follows:

$\mathrm{H}_{\mathrm{o}}$ : Common Effect Model

$\mathrm{H}_{1}$ : Fixed Effect Model

Under the condition $\mathrm{H}_{\mathrm{o}}$ will be rejected if P-value $<\alpha(\alpha=5 \%)$ and accepted if P-value $>0.05$ and the result appears in table 6.

Based on the result of Chow Test, it is shown that Cross Section probability of $0,0000<0,05$ thus the model selected is Fixed Effect Model

\subsubsection{Hausman Test (Random Effect Test)}

Hausman Test selects models by comparing Fixed Effect and Random Effect Model for preferable model.

Ho: Random Effect Model

H1: Fixed Effect Model

Under condition if P-value $<0,05$, Ho rejected and if P-value $>0,05$, Ho accepted. The result of Hausman Test shown on following table. 
Based on Hausman Test result it is revealed that cross-section F probability of $0.0000<0,05$. Thus, the selected model is Fixed Effect model and it is not necessary to execute Lagrange Multiplier Test caused Chow and Hausman Test produce the same result. Lagrange Multiplier Test is conducted to determine the preferable method between the common effect or random effect, through Chow and Hausman test the result is Fixed Effect is the better model than common and random effect model.

\subsection{Classical Assumption Test}

In fulfilling the assumption of BLUE (Best Linear Unbiased Estimation) minimal classical assumption test that must be executed is Multicollinearity, Heteroscedasticity and Autocorrelation test (Ekananda, M, 2016).

\subsubsection{Multicollinearity Test}

Table 6 shows the result of multicollinearity test.

Table 6. Multicollinearity Test Result

$\begin{array}{ccccccc} & \text { ROE } & \text { LEV } & \text { EPS } & \text { GROWTH } & \text { LIQUID } & \text { NDTS } \\ \text { ROE } & 1 & 0.39279097 \ldots & 0.26091592 \ldots & 0.27002719 \ldots & -0.3518667 \ldots & -0.0929266 \ldots \\ \text { LEV } & 0.39279097 \ldots & 1 & -0.0733824 \ldots & 0.11038599 \ldots & -0.7883882 \ldots & -0.0695304 \ldots \\ \text { EPS } & 0.26091592 \ldots & -0.0733824 \ldots & 1 & 0.01009858 \ldots & 0.02284661 \ldots & -0.0762982 \ldots \\ \text { GROWTH } & 0.27002719 \ldots & 0.11038599 \ldots & 0.01009858 \ldots & 1 & -0.1005203 \ldots & -0.1921020 \ldots \\ \text { LIQUID } & -0.3518667 \ldots & -0.7883882 \ldots & 0.02284661 \ldots & -0.1005203 \ldots & 1 & -0.0997276 \ldots \\ \text { NDTS } & -0.0929266 \ldots & -0.0695304 \ldots & -0.0762982 \ldots & -0.1921020 \ldots & -0.0997276 \ldots & 1\end{array}$

Source: 11,o version E-views Output

From table 6 . seen that all coefficient correlation between variables $<0.80$, therefore regression model free from multicollinearity problem.

\subsubsection{Heteroscedasticity Test}

Common Effect and Fixed effect are suspected to incur heteroscedasticity problem. This is observable after comparing the model with and without a weight (Lela, 2017). The result concluded that Fixed Effect model is preferable after identifying heteroscedasticity issue. The following are information on fixed Effect with and without weight is presented table 7 and 8.

Table. 7. Unweighted Fixed Effect Model

Dependent Variable: FIRMPER

Method: Panel Least Squares

Date: 09/06/20 Time: 11:56

Sample: 20142019

Periods included: 6

Cross-sections included: 18

Total panel (balanced) observations: 108

\begin{tabular}{lllll}
\hline Variable & Coefficient & Std. Error & t-Statistic & Prob. \\
\hline \hline C & 3.135548 & 1.101558 & 2.846467 & 0.0056 \\
ROE & -0.620453 & 0.452912 & -1.369919 & 0.1744 \\
LEV & -0.669489 & 1.539013 & -0.435012 & 0.6647 \\
EPS & $-7.87 \mathrm{E}-05$ & 0.000124 & -0.635778 & 0.5266 \\
GROWTH & 0.270485 & 0.685573 & 0.394539 & 0.6942 \\
LIQUID & 0.037544 & 0.142939 & 0.262656 & 0.7935 \\
NDTS & -4.926538 & 23.61279 & -0.208639 & 0.8352 \\
\hline \hline
\end{tabular}


Effects Specification

\begin{tabular}{llll}
\hline Cross-section fixed (dummy variables) & & \\
\hline \hline Root MSE & 0.886732 & R-squared & 0.951350 \\
Mean dependent var & 2.670648 & Adjusted R-squared & 0.938030 \\
S.D. dependent var & 4.038994 & S.E. of regression & $\mathbf{1 . 0 0 5 4 6 0}$ \\
Akaike info criterion & 3.041897 & Sum squared resid & 84.91978 \\
Schwarz criterion & 3.637927 & Log likelihood & -140.2625 \\
Hannan-Quinn criter. & 3.283566 & F-statistic & 71.41892 \\
Durbin-Watson stat & 2.104966 & Prob(F-statistic) & 0.00oooo \\
\hline \hline
\end{tabular}

Source: 11,o version E-views Output

Table 8. Weighted Fixed Effect Model)

Dependent Variable: FIRMPER

Method: Panel EGLS (Cross-section weights)

Date: 09/o6/20 Time: 14:40

Sample: 20142019

Periods included: 6

Cross-sections included: 18

Total panel (balanced) observations: 108

Linear estimation after one-step weighting matrix

\begin{tabular}{lllll}
\hline Variable & Coefficient & Std. Error & t-Statistic & Prob. \\
\hline \hline C & 3.390618 & 0.293832 & 11.53930 & 0.0000 \\
ROE & -0.267569 & 0.313245 & -0.854185 & 0.3954 \\
LEV & -1.071128 & 0.454776 & -2.355287 & 0.0208 \\
EPS & $3.62 E-05$ & $9.65 \mathrm{E}-05$ & 0.375420 & 0.7083 \\
GROWTH & -0.087669 & 0.154519 & -0.567368 & 0.5720 \\
LIQUID & -0.007906 & 0.023325 & -0.338937 & 0.7355 \\
NDTS & -7.957639 & 5.732597 & -1.388139 & 0.1688 \\
\hline \hline
\end{tabular}

\begin{tabular}{ll} 
NDTS & -7.957639 \\
\hline \hline
\end{tabular}

Cross-section fixed (dummy variables)

\begin{tabular}{llll}
\hline \hline & \multicolumn{2}{l}{ Weighted Statistics } & \\
\hline Root MSE & 0.815265 & R-squared & 0.923098 \\
Mean dependent var & 3.201408 & Adjusted R-squared & 0.902042 \\
S.D. dependent var & 1.744763 & S.E. of regression & 0.924424 \\
Sum squared resid & 71.78303 & F-statistic & 43.83928 \\
Durbin-Watson stat & 1.689085 & Prob(F-statistic) & 0.000000 \\
\hline \hline & Unweighted Statistics & 2.670648 \\
R-squared & 0.950113 & Mean dependent var & 2.149377 \\
\hline
\end{tabular}

Source: 11,o version E-views Output

In finding a preferable model, the comparation of two models seen on table 9 below.

Table. 9. The Comparation of Unweighted and Weighted Fixed Effect Model

\begin{tabular}{|l|c|c|}
\hline Parameter & Unweighted Fixed Effect Model & Weighted Fixed Effect Model \\
\hline Statistis t probability & No variables $<0.05$ & 1 variable $<0.05$ \\
\hline R-Squared & 0.951350 & 0.923098 \\
\hline F-Statistic Probability & 0.0000 & 0.0000 \\
\hline
\end{tabular}

Source: processed Data, 2020 
The significant difference between two models is on $\mathrm{t}$ statistics probability, where weighted fixed effect model is better than unweighted one. Therefore, the final model selected is weighted fixed effect Model exhibited on table 8.

\subsubsection{Autocorrelation Test}

Autocorrelation test performed to identify the presence of correlation between observation, whether in the form of time series or cross section. As panel data is characterized by time series and cross section, autocorrelation issue is ignored for such data type. (Ekananda, M, 2016).

\subsection{Hypotheses Test}

Model selection test concluded that fixed effect model is preferable model. Furthermore, heteroscedasticity test stated that weighted fixed effect model is better that unweighted version. Therefore, hypotheses test is based on weighted fixed effect model as presented in table 8 .

\subsubsection{The Determination Coefficient (Adjusted $R^{2}$ )}

As shown in Table 8, the Adjusted $\mathrm{R}^{2}$ value of 0,902042 would mean that all independent variables, namely Return on Equity (ROE), Leverage, Earning per Share (EPS), Growth, Liquidity and Non Debt Tax Shield, are able to describe Firm Performance amounting to 90,20\%. The Adjusted $\mathrm{R}^{2}$ value of $90,20 \%$ indicated that the effect of all independent variables on Firm Performance is strong because $>$ 0.50 .

\subsubsection{The F Statistics Test (simultaneously)}

As F-value sit at 43,83928 with probability of $0,000000<0,05$, it can be concluded that all independent variables, which are Return on Equity (ROE), Leverage, Earning per Share (EPS), Growth, Liquidity and Non Debt Tax Shield, affect Firm Performance collectively as demonstrated in panel data regression.

\subsubsection{The T-test (partial)}

It is found that only Leverage negatively affect Firm Performance since the probability of $0,0208<$ 0,05. The other five variables, which are ROE (o,3954), EPS (o,7083), Growth (o,5720), Liquid (o,7355) and NDTS $(0,1688)$, has no significant affect to firm performance.

\subsubsection{Multiple linear regression analysis}

Based on table 8. the regression equation can be formed as follows:

Firm Performance $(\mathrm{Y})=3.390618-0.267569$ (ROE) - 1.071128 (Leverage) + 3.62E-o5 (EPS) 0.087669 (Growth) - 0.007906 (Liquidity) - 7.957639 (Non-Debt Tax Shield)

The equation above can be explained as follows:

The constant value of 3.390618 shows that, when Return on Equity (ROE), Leverage, Earnings per Share (EPS), Growth, Liquidity and Non- Debt Tax Shield experience no change, then, the value of firm performance is 3.390618 .

ROE's coefficient is negative at $\mathbf{0 . 2 6 7 5 6 9}$. This means that when other independent variables is constant, any increase in ROE by 1 unit will decrease firm performance by 0.267569 and vice versa.

Leverage's coefficient is negative at -1.071128. This implies that when other independent variables is constant, any increase in leverage by 1 unit will decrease firm performance by 1.071128 and vice versa. 
The regression's coefficient value of EPS is at $+3.62 \mathrm{E}-05$. This means that any increase in EPS by 1 unit will increase firm performance by $3.62 \mathrm{E}-05$, given that other independent variables is assumed to be constant and vice versa.

The growth's coefficient is at -0.087669. This implies that when other independent variables assumed constant, any increase of growth by 1 unit will decrease firm performance by 0.087669 and vice versa.

The regression coefficient of Liquidity is at 0.007906 . This means that any increase in Liquidity by 1 unit will decrease firm performance by 0.007906 , given that other independent variables assumed constant.

The NDTS coefficient is at -7.957639 . This implies that when other independent variables assumed constant, any increase of NDTS by 1 unit will decrease firm performance by 7.957639 and vice versa.

\section{Discussion}

\subsection{The Effect of Return on Equity on Firm Performance.}

The result of statistical test concludes that ROE does not affect firm performance. The possible explanation is that from measurement side, ROE calculated as a proportion of net income to equity, while firm performance proxied with Tobin's $Q$ formula calculated as the proportion of market value of outstanding share to total asset. Therefore, the effect of ROE is indirect through the fluctuation of total asset as result of net income fluctuation. In other word, net income fluctuation of manufacturing firm listed in IDX between 2014 to 2019 is not strong enough to push firm performance to change. That is, ROE does not significantly affect firm performance

\subsection{The Effect of Leverage on Firm Performance.}

The test shows that leverage negatively and significantly affect firm performance. It is in line with trade off and Pecking Order theory, which state that at a certain point leverage affect negatively and in other point change to positive affect. When leverage produces net income in the form of sufficient asset fluctuation to push firm performance to change, leverage affects firm performance as suggested by Al Azam (2014),Wydia et al. (2015) and Jafari (2015).

\subsection{The Effect of EPS on Firm Performance}

The result shows that EPS does not significantly affect firm performance, which is in contrast to concept in finance that advise that income affects firm's performance. The possible explanation on this comes through its measurement, where EPS calculated as a proportion of net income to outstanding share, while Firm Performance is measured with Tobin's Q formula, calculated as proportion of outstanding share market value to total asset. From this view, there are three factors affecting firm performance, namely are net income, share market price and total asset. On the other hand, share price is external factor precepted as given factor. Therefore, EPS will affect firm performance only if net income is generated from the efficient operation in using of total asset. In other word, EPS does not affect firm performance because it is inefficient in using asset to obtain income.

\subsection{The Effect of Growth on Firm Performance}

Statistical test result shows that growth does not significantly affect firm performance. The condition that drives growth does not affect firm performance because growth is related to change in total asset that not necessarily relate and influence fluctuation of firm performance. 


\subsection{The Effect of Liquidity on Firm Performance}

Result shows that liquidity does not significantly affect firm performance. The reasonable explanation is that liquidity as a proxy of financial sound does not always perceive to be a good news for investor. Instead, market price becomes relatively stable. Therefore, liquidity does not affect firm performance.

\subsection{The Effect of Non-Debt Tax Shield (NDTS) on Firm Performance.}

The result of statistical test suggests that NDTS does not affect firm performance. NDTS is calculated as a proportion of depreciation expense to total asset, while firm performance is a proportion of outstanding share market price to total asset. Thus, the driving factor is on depreciation expense and share price. Most of depreciation expense of observed firms are relatively stable. This made NDTS to be unrelated to Firm Performance.

\section{Conclussion and Suggestion}

Simultaneously, all independent variables represented by ROE, Leverage, EPS, Growth, Liquidity and Non-Debt Tax Shield (NDTS) strongly affect Firm Performance, but form these variables partially, only Leverage has a negative significant effect on Firm Performance. This study implies that all firm management is suggested to consider ROE, Leverage, EPS, Growth, Liquidity and Non-Debt Tax Shield (NDTS) in their strategy planning of performance achievement.

Considering that all independent variables, namely ROE, Leverage, EPS, Growth, Liquidity and Non-Debt Tax Shield (NDTS) strongly affect Firm Performance, even in partial manner, thus, it is only leverage that has negative significant effect on firm performance. Therefore, it is suggested to further researcher to re-observe the effect of the rest variables to Firm Performance to find a better result that correspond with established financial concept by adding the long of time in period.

\section{References}

Al-Matari, Ibrahim Mohammed; Al-Swidi, Abdullah Kaid; Bt Fadzil, Faudziah Hanim (2014). The Measurements of Firm Performance's Dimensions. Asian Journal of Finance and Accounting, vol 6, No. 1. DOI: https://doi.org/10.5296/ajfa.v6i1.4761

Al-Nimer, Munther; Ward, Lina; Al-Omari, Rania. (2015). The Impact of Liquidity on Jordanian Banks Profitability through Return on Asset. European Journal of Business and Management. Vol 7, No 7. DOI: https://doi.org/10.32479/ijefi.8304

Alazzam, Farouq Ahmad. (2014). The Measuring the impact of Some Determinants of Return on Investment in Industrial Companies in Aqaba City. Business Management and Strategy, Vol 6, No. 2 DOI: https://doi.org/10.5296/bms.v5i2.6067.

Al-Jafari, Mohamed Khaled; Al Samman, Hazem. (2015). Determinants of Profitability: Evidence from Industrial Companies Listed on Muscat Securities Market. Review of European Studies, Vol 7, No. 11. DOI: 10.5539/res.v7n11p303

Al-Qaisi, Fozan; Tahtamouni, Asem; Al-Qudah, Mustafa. (2016). Factots Affecting the Market Stock Price-The Case of the Insurance Companies Listed in Amman Stock Exchange. American University of Madaba, Jordan.

Al-Tamimi, Hussein A. Hassan; Rahman, A.A. Abdel; Alwan, Ali. (2011). Factots Affecting Stock Prices in the UAE Financial Markets. Journal of Transnational Management. DOI: 10.1080/15475778.2011.549441

Anastasia Nwakaego Duru1; Michael Chidiebere Ekwe2; Grace Chinyere Eje3, 2014. Liquidity Positioning and Firm Performance in Industrial/Domestic Product Companies: Evidence from Nigeria. IOSR Journal of Economics and Finance (IOSR-JEF), Volume 5, Issue 6. Ver. II, PP 25-32.

Burja, Camelia (2011). Factors Influencing The Companies Profitability. Annales Universitatis Apulensis Oeconomica, Vol 13. No 2. DOI: 10.29302/oeconomica.2011.13.2.3

Brigham, Eugene F; Houston, Joel F.(2014). Fundamental of Financial Management, University of Florida, Thomson Southwestern, USA 
Berk, Jonathan; DeMarzo, Peter.(2011).Corporate Finance, second edition,Stanford University, Pearson International, USA

Calistus Wekesa Waswa, 1Mohamed Suleiman Mukras \& 1David Oima, 2018. Effect of Liquidity on Financial Performance of the Sugar Industry in Kenya. International Journal of Education and Research, Vol. 6 No. 6

Ekananda, M (2016). Analisis Ekonometrika Data Panel (kedua), Mitra Wacana Media, Jakarta.

Friedman AL and Miles, S (2006). Stakeholder Theory and Practice. Oxford University Press

Grace Akenga, 2017. Effect of Liquidity on Financial Performance of Firms Listed at the Nairobi Securities Exchange, Kenya. International Journal of Science and Research (IJSR). Volume 6 Issue 7. DOI: $10.21275 /$ ART20175036.

Higgins, Robert C; Koski, Jennifer L.; Milton, Tood (2016). Analysis for Financial Management. McGraw-Hill Education, New York.

Hansen, Don R \& Mowen, Maryanee M. (2007). “Managerial Accounting”. $8^{\text {th }}$ edition, Thomson Southwestern.

Jayasiri, Nuradhi. (2015). The Cause-Effect Relationship between Growth and Profitability, Evidence from Listed Manufacturing Companies in Sri Lanka. Conference Peradeniya University International Research Session (PURSE).

Jensen, M. C. (2001). Value maximization, stakeholder theory, and the corporate objective function. Journal of Applied Corporate Finance, 14(3), 8-21. doi: 10.1111/j.1745-6622.2001.tboo434.x

Kartal Demirgüneș, 2016. The Effect of Liquidity on Financial Performance: Evidence from Turkish Retail Industry. International Journal of Economics and Finance 8(4):63. DOI: 10.5539/ijef.v8n4p63

Lela Nurlaela Wati, (2018). Metodologi Penelitian Terapan. Pustaka Amri, Jakarta.

Mohammad Yameenı Najib H. S. Farhanı Mosab I. Tabash2, 2019. The Impact of Liquidity on Firms' Performance: Empirical Investigation from Indian Pharmaceutical Companies. Academic Journal of Interdisciplinary Studies Vol 8 No 3. Doi: 10.36941/ajis-2019-0o19

Rudi Bratamanggala. (2018). The Factors Affecting Board Stock Price of LQ45 Stock Exchange 2012-2016; Case of Indonesia. European Research Studies Journal Volume XXI, Issue 1. DOI: 10.35808/ersj/934.

Murugesan Selvam, Jayapal Gayathri, Vinayagamoorthi Vasanth, Kasilingam Lingaraja, Sigo Marxiaoli, (2016). Determinants of Firm Performance: A Subjective Model. The International Journal of Social Science Studies vol o4, no 7. DOI: https://doi.org/10.11114/ijsss.v4i7.1662

Santos, Juliana Bononi; Brito, Luiz Artur Ledur (2012). Toward Subjective Measurement for Firm Performance. Brazilian Administration Review, V. 9, Special Issue, art 6. DOI:10.1590/S1807-76922012000500007

Saleem, Qasim; Rehman, Ramiz Ur.(2011). Impacts of Liquidity ratios on profitability. Multidiciplinary Journal of Research in Business. Vol 1, Issue 7.

Sharif, Taimur; Purohit, Harsh : Pillai, Rekha. (2015). Analysis of Factors Affecting Share Prices : The Case of Bahrain Stock Exchange. International Journal of Economics and Finance, Vol 7, No. 3 . DOI:10.5539/IJEF.V7 $\mathrm{N}_{3} \mathrm{P}_{207}$

Sritharan, Vinasithamby, 2015. Do tax shields of debt and non - debt impact on firms' performance? Evidence from Sri Lankan Land and property sector. Research Journal of Economics and Business Studies, Vol 04 No 05.

Titman, Sheridan; Keown, Arthur J.; Martin, John D. (2014). Financial Management Principles and Applications. Pearson Education Limited.

Wydia Retno Utami; Sri Hartoyo dan Tubagus Nur Ahmad Maulana. (2015). The Effect of Internal and External Factors on Stock Return: Empirical Evidence from the Indonesia Construction Subsector. Asian Journal of Business and Management, Vol 8, Issue 5 